\title{
In VIVO: onderwijskundige principes in de klinische praktijk!
}

Mijn hoofd is vol van In VIVO en het huidige TMO levert gelukkig weer leesvoer dat ik in dat kader kan verteren. Waar staat 'In VIVO' voor? Het is het acroniem voor het landelijke project 'Vaart in Innovatie Vervolgopleidingen'. Waar onderwijskundigen vijf jaar geleden nog nauwelijks grip kregen op de klinische opleidingspraktijk, worden momenteel in het kader van In VIVO teams samengesteld van onderwijskundigen uit de UMCs, gynaecologen en kinderartsen. Die teams gaan een stimulerende en coachende rol innemen bij het in de praktijk brengen van de nieuwe opleidingsplannen voor de vervolgopleidingen gynaecologie en kindergeneeskunde zoals verwoord in de curricula HOOG en GOED (http://www. medischevervolgopleidingen.nl). Onder leiding van de door VWS geïnstalleerde stuurgroep MOBG (Modernisering Opleidingen Beroepsuitoefening Gezondheidszorg) en gefinancierd door VWS en veldpartijen, waarvan de Nederlandse Federatie van UMCs momenteel de boventoon voert, wordt deze 'try out' van het herziene klinische opleiden onder de naam 'In VIVO' in gang gezet. Bovendien wordt een evaluatie verricht van de kosten (tijd en geld) en baten (met name haalbaarheid en effect) van deze eigentijdse vorm van opleiden, als ook een studie van succes- en faalfactoren bij de implementatie.

Kenmerken van de herziene opleidingen zijn:

- Competentiegericht volgens de gemodificeerde CanMEDS.

- Intensiever appèl op zelfsturing.
- Een toetsmix met naast kennistoetsing en toetsing van simulaties ook praktijkobservaties en teambeoordelingen.

- Portfolioleren met bijbehorende voortgangsgesprekken.

- Transparantie: diverse graden van bekwaamheid, uitgedrukt in zelfstandigheid, te behalen op deelaspecten van het vak binnen bepaalde termijnen (resultaten op een tijdbalk).

- Flexibiliteit in opleidingsschema's en opleidingsduur.

Ieder kenmerk kent zo zijn eigen zorgpunten. Het competentiegericht opleiden bijvoorbeeld is noodzakelijk, omdat de rol van de specialist verandert. Wie de krant leest, weet dat gebrekkige communicatie, samenwerking, organisatie en professioneel gedrag even goed tot ongelukken leiden als gebrekkige medische expertise. Het is voor de gemiddelde klinische opleider echter niet eenvoudig de dagelijkse praktijk en met name de opleiding te bezien in de abstracte terminologie van het competentieprofiel zoals beschreven in de CanMEDS. De opleiders zijn gewend taken in de praktijk te beoordelen zonder al te veel abstractie. Het zal de kunst zijn de CanMEDS concreet te maken voor de opleiders en voor de aios. In dit TMO besteden Spermon et al. aandacht aan een onderwijskwalificatie die studenten en aios kunnen halen. Voor de toekomst wordt op die manier een onderwijskundig onderlegd kader gekweekt. Bij het In VIVO-project wordt feitelijk een inhaalactie ondernomen om opleidingsteams uit de klinieken hun aios klaar te stomen voor het deskundige gebruik van eigen- 
tijdse onderwijsideeën en bijbehorende middelen.

Ook de zelfsturing is een lastig onderwerp. De meeste aios zoeken niet de confrontatie met hun opleidingssysteem, hoe inefficiënt en frustrerend dat systeem ook kan zijn. Zelfsturing eist reflectie, het formuleren van doelen en het onderhandelen met de omgeving om die doelen te kunnen bereiken. Het gaat hier om een gedragsverandering van de aios in de richting van een vrijwel gelijkwaardige gesprekspartner van de opleider, en dat in deze hiërarchische omgeving! De zelfsturing zal wel goed begeleid moeten worden! Bos et al. geven aan hoe zij studenten biomedische wetenschappen coachen bij zelfsturing. Zij besluiten hun betoog met de stelling dat van iemand een zelfsturende student maken heel wat anders is dan iemand alles zelf uit te laten zoeken.

De toetsing gaat verbeterd worden. Zelfbeoordeling valt in de praktijk niet mee, en de aios kan veel baat hebben bij een goede spiegel die voorgehouden wordt door opleiders en het team van professionals waarmee de aios werkt. Het is echter voor zowel de opleiders als de aios een 'kunst' om goed gebruik te leren maken van de toetsmix. Er worden van de opleider wel veel nieuwe onderwijskundige vaardigheden gevraagd en de aios moet plotseling kunnen helicopteren en constructief kunnen omgaan met feedback. Portfolioleren en goede voortgangsgesprekken vragen serieuze aandacht en tijdbesteding. Momenteel worden voortgangsgesprekken veelal gebaseerd op de al of niet ontstane problemen op de werkvloer en op grond van de sfeer die iemand om zich heen oproept. Het zijn vaak snelle gesprekken die niet erg diep gaand zijn. Er is veel te leren en te oefenen. In de toekomst zullen aios die uit het schakeljaar in de opleiding komen, zoals Heineman in dit TMO-nummer beschrijft, ge- wend zijn aan deze manier van toetsing. Heineman beschrijft treffend hoe de basisopleiding en de vervolgopleiding vloeiend in elkaar kunnen overlopen.

De opleiding wordt transparanter. Van den Berg et al. beschrijven hoe rolmodellen de specialismekeuze beïnvloeden. Zij laten zien hoe belangrijk rolmodellen eigenlijk zijn. Tot voor kort bepaalden rolmodellen ook de leerdoelen voor de aios. De aios keek eindtermenlijsten niet of zelden in. Op grond van het functioneren van het opleidingsteam bepaalde de aios de eigen professionele doelen. In de herziene curricula zijn duidelijke resultaten gedefinieerd die moeten worden behaald binnen een bepaalde tijd. De resultaten zijn omschreven als bekwaamheidsverklaringen. Een aios bekwaam verklaren voor het zelfstandig behandelen op risicovolle terreinen is voor een opleider een vorm van ultieme toetsing. Hier druist het competentiegericht toetsen tegen het gevoel van de clinicus in. Iemand kan misschien goed de indicatie stellen tot een sectio, die goed uitvoeren, goed communiceren, samenwerken, organiseren en professioneel zijn, maar geldt dat nu dan ook voor de indicatie en uitvoering van een uterusextirpatie? Competenties zoals in de CanMEDS beschreven, zijn in geval van toetsing een soort surrogaatmarkers! Om een aios bekwaam te verklaren, wil de opleider de aios in de praktijk zien en beoordelen bij duidelijk omschreven holistische activiteiten.

Een dergelijke herziene opleiding zal snelle en tragere leerlingen herkennen. Flexibiliteit van de opleidingsduur lijkt vanzelfsprekend. Aios spelen echter een rol in de bedrijfsvoering en enthousiaste opleiders hebben leerzame stages ingericht met een plaats en een tijdsduur. Hierin te gaan variëren is heel frustrerend voor de opleidingsmanagers. Echter, waar een aios de burger tussen de 110 en 140 duizend euro's 
per jaar kost, is inefficiëntie in de opleiding letterlijk niet te verkopen. Er spelen hier conflicterende belangen. Het zal niet zonder slag of stoot verlopen.

Met In VIVO willen we dus nogal wat! Het moet een leercasus worden waarvan de andere specialismen moeten profiteren, enerzijds bij het schrijven van hun opleidingsplannen, anderzijds bij het vervolgens invoeren van die plannen. In VIVO wordt voer voor verandermanagers. Er zijn verscheidene cultuurbreuken bijeen gevoegd, zodat kritische succes- en faalfactoren op verschillende terreinen in beeld zullen komen. Over de te volgen opleidingsmethodiek zijn we het in grote lijnen eens geworden, over de opleidingslogistiek zullen nog de nodige disputen losbarsten. We leven in Nederland in een bijzondere fase voor het medisch onderwijs. De kliniek wordt bereikt door de medische onderwijskundigen! Er zullen nog vele pagina's van TMO gevuld worden met de komende avonturen.

\section{Fedde Scheele}

